\title{
Early Cretaceous greywacke from Colville Knolls, New Zealand
}

N. Mortimer, C.J. Adams

GNS Science, Private Bag 1930, Dunedin 9054, New Zealand

I.C. Wright

Vice-Chancellor's Office, University of Canterbury, Private Bag 4800, Christchurch, New

Zealand

Revised version submitted

\begin{abstract}
Blocks of greywacke sandstone were dredged from the Colville Knolls, on the margin of the Zealandia continent, in 1989. Re-examination shows them to be quartz-poor feldspathic litharenites similar to those recorded from the basement, rather than sedimentary cover, of the North Island. U-Pb dating of detrital zircons reveals significant age populations at $107 \mathrm{Ma}, 115$ Ma, $122 \mathrm{Ma}$, and $245 \mathrm{Ma}$. These compositions and ages best match those of Waipapa Composite Terrane greywacke basement on nearby Great Barrier Island. As such, an earlier Waipapa correlation is preferred, but Colville Knolls detrital petrography and zircon ages also resemble those from some Early Cretaceous Torlesse Composite Terrane greywackes. Irrespective of terrane correlation, Colville Knolls is a submarine outcrop of Cretaceous greywacke deposited at the toe of the Gondwana Mesozoic accretionary wedge, and likely represents the outer, northeastern margin of Zealandia continental crust.
\end{abstract}

\section{Introduction}

The Colville Knolls are an irregularly-shaped positive bathymetric feature c. $120 \mathrm{~km}$ east of Great Barrier Island, New Zealand (Figure 1). The crest of the knolls lie in c. $750 \mathrm{~m}$ water depth along a southwestern extension of the Colville Ridge, but the Colville Ridge (Parson and Wright 1996; Wright 1997) is topographically and geologically separate from the Colville Knolls. The steep eastern slopes of the knolls descend to c. $2000 \mathrm{~m}$ water depth and define the western edge of the Havre Trough, a Plio-Pleistocene intra-arc basin (Wright et al. 1996). 
In 1989, scientists on $R / V$ Rapuhia cruise 2032 recovered c. $9 \mathrm{~kg}$ of jointed greywacke blocks from Colville Knolls at dredge stations X150 in c. 1320-1247 m water depth and X152 in c. 940-820 m water depth (Gamble et al. 1993). The Colville Knolls greywackes were correlated with the Mesozoic Waipapa Terrane basement of the North Island (Figure 1; Spörli 1978), based on their petrography and whole-rock geochemical composition (Gamble et al. 1993). Colville Knolls is an important greywacke basement sample site that helps define the limits of Zealandia's continental crust against surrounding ocean basins (Mortimer 2008).

Spörli (1978) presented a simple, longstanding and still-used subdivision of North Island basement. In this, Triassic-Jurassic volcaniclastic sandstone-dominated Waipapa Composite Terrane lies west of Taupo Volcanic Zone and Triassic-Early Cretaceous quartzofeldspathic-sandstone-dominated Torlesse Composite Terrane lies east of Taupo Volcanic Zone (Figure 1). Since the 1990s, numerous datasets of detrital zircon U-Pb ages from basement greywackes have been published (e.g., Ireland et al. 1992; Cawood et al. 1999; Adams et al. 1998, 2009, 2012, 2013). This U-Pb work has complemented and advanced the 1980s-1990s terrane framework based on petrographic and geochemical data (e.g. Mortimer, 1994). The U-Pb work underpins the modern basement terrane framework of the North Island as depicted on regional maps (e.g., Leonard et al. 2010). Spörli’s (1978) simple two-fold petrotectonic division has thus developed and changed: the Torlesse Composite Terrane is now divided into a Jurassic Kaweka Terrane and an Early Cretaceous Pahau Terrane (Adams et al. 2009), and the Pahau has some volcaniclastic parts (Mortimer 1994). Also, Early Cretaceous greywackes have been found within the Waipapa Composite Terrane on Great Barrier Island (Adams et al. 2009, 2012).

The purpose of this note is to present the results of further work on the Gamble et al. (1993) Colville Knolls greywackes, particularly U-Pb dating of detrital zircons. Using these new data we compare the sample with North Island basement terranes and briefly discuss the tectonic implications.

\section{Procedures}

In September 2008, four pieces of greywacke from dredge site X150 and two from X152 were extracted from the NIWA rock collection, and are now additionally catalogued in GNS 
Science's National Petrology Reference Collection (Strong et al. 2016) as P78547-49 and 78550-51 respectively. P78547 was additionally catalogued as R24690 and COLK1 in GNS Science's Nuclear Science Rock Collection. These were similar, but physically separate, samples to the 150/1 and 152/4 samples described and analysed by Gamble et al. (1993).

Zircons were extracted from R24690 by crushing the rock to $<300$ micron in a tungsten carbide mill, and sinking heavy (relative density $>2.9$ ) minerals in sodium polytungstate solution. Small, 40-150 micron, euhedral zircons were handpicked from this heavy mineral concentrate. Techniques and worksflows for zircon dating are described in Jackson et al. (2004) and Adams et al. (2012). The laser spots chosen for dating were typically at dihedral crystal terminations, thus representing the youngest stage of zircon growth. A summary of the ${ }^{206} \mathrm{~Pb} /{ }^{238} \mathrm{U}$ age dataset is given in Table 1 , and full $\mathrm{U}-\mathrm{Pb}$ isotopic ratio and age data are given in Supplementary File 1.

For consistency of approach, interpretation of detrital U-Pb ages follows procedures in Adams et al. (2012). Weighted mean ages of zircon populations were identified using the 'Unmix ages' routine of ISOPLOT3 (Ludwig 2003). Furthermore, zircon populations are only described as 'significant' if at least four grains contribute, comprise at least $4 \%$ of the total dataset, and have ${ }^{206} \mathrm{~Pb} /{ }^{238} \mathrm{U}$ and ${ }^{207} \mathrm{~Pb} /{ }^{235} \mathrm{U}$ ages that overlap with $95 \%$ confidence (Adams et al. 2012).

\section{Description}

Jointed greywacke on Colville Knolls is seen in bottom camera images at station X151 (Gamble et al. 1993, figure 4H). Our examination of hand samples from stations X150 and X152 indicates they are dark grey, hard, brittley-sheared, fine-grained subangular, poorlysorted greywacke sandstone. Disrupted mudstone-argillite beds up to $1 \mathrm{~cm}$ thick are present. Secondary minerals include quartz, calcite, chlorite, sericite and possibly pumpellyite; calcite veins, up to $1 \mathrm{~mm}$ thick, cut the samples. Undated micritic foram limestone infills occasional cracks.

Sample R24690 is representative of the greywackes (Figure 2). Visually-estimated percentages of its detrital minerals and matrix were 5\% quartz, 30\% plagioclase, $5 \% \mathrm{~K}$-feldspar (confirmed by staining), $49 \%$ lithic volcanic clasts, $1 \%$ lithic sedimentary clasts, $1 \%$ biotite, $<1 \%$ muscovite, $<1 \%$ epidote, $5 \%$ mudstone matrix, $5 \%$ calcite veins (all percentages are 
approximate). These modes transform to the following standard petrological ratios: $\mathrm{Q}: \mathrm{F}: \mathrm{L}=6: 39: 55, \mathrm{P} / \mathrm{F}=0.85, \mathrm{Lv} / \mathrm{L}=0.98$. The sandstone is thus a quartz-poor feldspathic litharenite. Lithic volcanic textures indicate a wide range of compositions from mafic, intermediate and felsic, with no one type dominant.

\section{$\mathrm{U}-\mathrm{Pb}$ analytical results}

A combined histogram and probability density plot of the age of detrital zircon ages from R24690/P78547 from Colville Knolls site X150 is shown in Figure 3A, and is compared in Figure 3B with two other Cretaceous volcaniclastic sandstones from North Island (see Figure 1 for locations) that were analysed using similar procedures. Detrital zircon ages of the Colville Knolls greywacke fall into a dominantly Cretaceous group (56\%). The youngest grain age, $94 \pm 1 \mathrm{Ma}$, might suggest a maximum, Cenomanian, depositional age. However, this zircon has ${ }^{206} \mathrm{~Pb} /{ }^{238} \mathrm{U}$ and ${ }^{207} \mathrm{~Pb} /{ }^{235} \mathrm{U}$ ages that are slightly discordant at $95 \%$ error limits, and thus a more conservative, maximum age estimate is provided by the youngest significant age component of the Cretaceous group, at $107 \pm 1 \mathrm{Ma}$ (16\% of all dated zircons). This indicates Urutawan or later deposition (using the timescale of Raine et al. 2015). Further, significant Cretaceous zircon age components at $115 \pm 1$ and $122 \pm 2 \mathrm{Ma}$, represent respectively $16 \%$ and $11 \%$ of the total. Of the pre-Cretaceous zircons, there is a latest Permian-Early Triassic component at $245 \pm 3 \mathrm{Ma}$, and c. $20 \%$ of the total are pre-Permian mostly of Carboniferous and Cambrian-Neoproterozoic age.

\section{Discussion}

\section{Basement vs cover correlation}

On the basis of petrography and whole rock geochemistry, Gamble et al. (1993) correlated the Colville Knolls greywackes with the Waipapa Terrane of the North Island. But, with a maximum stratigraphic age of $107 \pm 1 \mathrm{Ma}$, the fine-grained sandstones of Colville Knolls could alternatively be indurated Late Cretaceous (or younger) sandstones of the Zealandia Megasequence. This latter correlation was not discussed by Gamble et al. (1993) but must be considered a possibility, especially as Adams et al. (2013) noted that more than half the ages of detrital zircons from the Late Cretaceous ( $<100 \mathrm{Ma}$ ) Punakitere Sandstone of the Northland 
Allochthon Zealandia Megasequence have zircon age spectra broadly similar to R24690, with significant 131-96 Ma age components and lesser, but subequal, proportions of Permo-Triassic, Devonian-Carboniferous, and Precambrian zircons.

Our examination of Punakitere Sandstone thin sections in the GNS P collection reveals that they have subequal Q:F:L proportions, contain prominent detrital biotite and muscovite, commonly have a calcareous matrix and/or carbonaceous detritus, are usually moderatelysorted, and have substantial amounts of sedimentary lithic clasts (i.e. low Lv/L) (see also Isaac et al. 1994; Hayward 2017). All these observations differ from the petrographic properties of P78547 and other Colville Knolls greywackes. Thus, with moderate confidence, we can rule out a Zealandia Megasequence correlation of the Colville Knolls indurated sandstones and confirm that Colville Knolls is indeed true basement terrane greywacke. The cataclastic nature of the greywacke postdates metamorphism and can possibly be attributed to rift margin faulting associated with back-arc extension of the Havre Trough - offshore Taupo Volcanic Zone (Parson and Wright 1996; Wysoczanski et al. 2019) and/or the Vening Meinesz Fault Zone (Figure 1).

\section{Waipapa vs Torlesse Terrane correlation}

Early Cretaceous Great Barrier Island greywackes are the nearest onland Waipapa Composite Terrane basement terrane exposure to the Colville Knolls. They lie c. $120 \mathrm{~km}$ to the west of the dredge sites (Figure 1). The match in detrital zircon age components between the Colville Knolls and two Great Barrier Island samples reported by Adams et al. (2013) is fair (Figure $3 \mathrm{AB}$ ); greywackes from the island have major detrital zircon age components at 267, 249, 225, and $134 \mathrm{Ma}$ (R23783) and 251, 152, 138, 135 and $112 \mathrm{Ma}$ (R23787) respectively (Figure 3B).

Based on seafloor bathymetry compiled from numerous multibeam tracks (i.e. more detailed than shown in Figure 1), Wysoczanski et al. (2010, figure 4) noted a strong NW-SE trend of Havre Trough rift and ridge axes. More significant from a kinematic point of view was their identification of a minor but consistent cross-rift structural trend of azimuth $310^{\circ}$ and long wavelength cross-arc gravity anomalies of trend 317 . These are essentially parallel to the crossarc volcanic trails interpreted by Wright et al. (1996) and both directly indicate the progressive opening direction of the Havre Trough since at least c. $5 \mathrm{Ma}$, but possibly young as $<2 \mathrm{Ma}$ (Wysoczanski et al. 2019). Thus, in a pre-Pliocene, pre-Havre Trough, pre-Taupo Volcanic 
Zone reconstruction, the Colville Knolls would have rifted from a position on the eastern edge of Raukumara Basin somewhere between what are now Clark and Whakatane volcanoes, i.e. c. $120 \mathrm{~km}$ north of R24206 greywacke at Whanarua Bay (Figure 1). Thus, greywackes of the onland Pahau Terrane of the Torlesse Composite Terrane were once spatially as close to Colville Knolls as those in onland Waipapa Composite Terrane. Thus it is not surprising that there is a fair to good match in detrital zircon patterns between the Colville Knolls greywacke and eastern Bay of Plenty Pahau Terrane (Torlesse Composite Terrane) greywacke with age peaks at $355,127,116$ and $102 \mathrm{Ma}$ - arguably almost as good as with the Great Barrier Island greywackes (Figure 3B).

Similarities in detrital zircon patterns, whole rock composition and $\mathrm{Sr}, \mathrm{Nd}$ and $\mathrm{Pb}$ isotope ratios between Pahau Terrane of Torlesse Composite Terrane and the younger parts of the Waipapa Composite Terrane have been noted by Adams et al. (2013) and Price et al. (2015). The 120-100 Ma zircon age components plausibly correlate with, and are caused by, Early Cretaceous lithic volcaniclastic input which variably dilutes the background PermoTriassic and Cambrian-Precambrian age group Torlesse zircon populations (Adams et al. 2013). Both of these latter groups are a characteristic feature of Torlesse zircon age patterns in general, including the Pahau Terrane. Thus, Sporli's (1978) simple twofold Waipapa and Torlesse classification of North Island basement is challenged by the Early Cretaceous volcaniclastic Great Barrier Island and Colville Knolls samples, whose critical field contacts are masked by Taupo Volcanic Zone eruptives and ocean. For simplicity we preferentially correlate Great Barrier Island and Colville Knolls greywackes with Waipapa Composite Terrane on the basis of spatial proximity and detrital mineralogy, but note that all three samples (Figure 3) are younger than any other dated Waipapa Terrane material. An alternative, Pahau Terrane of Torlesse Composite Terrane, correlation is plausible on the basis of age and detrital mineralogy and (on closing the Havre Trough) spatial proximity. Should contiguous geographic area, stratigraphic age, whole rock composition or detrital zircon spectra be the principal defining feature of New Zealand basement terranes? A definitive answer to this question would require a comprehensive review of multiple datasets and is outside the scope of this short note.

\section{Are the Colville Knolls allochthonous?}


In addition to the opening of the Havre Trough, another issue affecting the original Cretaceous position of the Colville Knolls along the Zealandia margin is whether they lie north or south of the c. 800 km-long, dextral strike-slip fault, the Vening Meinesz Fault Zone (VMFZ; Figure 1; Herzer et al. 2009). The VMFZ is a sharply-defined continent-ocean boundary fault scarp at its NW end. But, at its SE end, it splays and cannot be traced in sparse seismic reflection profiles beneath the Northland continental shelf (Isaac et al. 1994; Herzer et al. 2009; Figure 1). As such it is not currently clear if the Colville Knolls lie north or south of the main VMFZ fault strand; our new geochronological data shed no light on this matter. We have a weak preference that Colville Knolls lie to the north of the VMFZ. If this is the case then, prior to movement on the VMFZ in the Miocene (Herzer et al. 2009), the Colville Knolls lay some $300 \mathrm{~km}$ further $\mathrm{NE}$, and represent a piece of Zealandia translated from near North Cape.

\section{Conclusions}

We have further examined and analysed the Colville Knolls greywacke dredge samples reported by Gamble et al. (1993). We confirm that the greywackes are quartz-poor feldspathic litharenites as occur throughout the Waipapa Composite Terrane (Sporli 1978; Adams et al. 1998) and, locally, within the Torlesse Composite Terrane (Mortimer, 1994), but not within sedimentary cover of the Zealandia Megasequence. Significant detrital zircon populations of $107 \mathrm{Ma}, 115 \mathrm{Ma}, 122 \mathrm{Ma}$, and $245 \mathrm{Ma}$ are present. These match nearby Early Cretaceous greywacke basement on Great Barrier Island, so the correlation of Gamble et al. (1993) with Waipapa Composite Terrane basement is confirmed. However, the inferred Early Cretaceous depositional age, similarity of petrography and zircon age spectra to some Torlesse Composite Terrane greywackes, former proximity to the proto-Colville-Kermadec Ridge, and uncertain position with respect to the Vening Meinesz Fracture Zone mean there are as-yet unresolved uncertainties to the terrane correlation and original position within Zealandia of the Colville Knolls greywackes.

\section{Acknowledgements}

We thank Scott Nodder for hospitality at NIWA while one of us (Mortimer) subsampled the Colville Knolls rocks. Neville Orr made thin sections, and Stephen Tulloch created the image in Figure 2. Julie Rowland, an anonymous referee and editor Richard Wysoczanski are 
acknowledged for formal reviews. This work was funded by a New Zealand Ministry of Business, Innovation and Employment (MBIE) core grant to GNS Science.

\section{References}

Adams, CJ, Campbell HJ, Graham IJ, Mortimer N. 1998. Torlesse, Waipapa and Caples suspect terranes of New Zealand: integrated studies of their geological history in relation to neighbouring terranes. Episodes. 21:235-240.

Adams CJ, Mortimer N, Campbell HJ, Griffin WL. 2009. Age and isotopic characterisation of metasedimentary rocks from the Torlesse Supergroup and Waipapa Group in the central North Island, New Zealand. New Zealand Journal of Geology and Geophysics. 52:149170.

Adams CJ, Mortimer N, Campbell HJ, Griffin WL. 2012. The mid-Cretaceous transition from basement to cover within sedimentary rocks in eastern New Zealand: evidence from detrital zircon age patterns. Geological Magazine. 150:455-478.

Adams CJ, Mortimer N, Campbell HJ, Griffin WL. 2013. Detrital zircon geochronology and sandstone provenance of basement Waipapa Terrane (Triassic-Cretaceous) and Cretaceous cover rocks (Northland Allochthon and Houhora Complex) in northern North Island, New Zealand. Geological Magazine. 150:89-109.

Cawood PA, Nemchin AA, Leverenz A, Saeed A, Ballance PF. 1999. U/Pb dating of detrital zircons: implications for the provenance record of Gondwana margin terranes. Geological Society of America Bulletin. 111:1107-1119.

Gamble JA, Wright IC, Baker JA. 1993. Seafloor geology and petrology in the oceanic to continental transition zone of the Kermadec-Havre-Taupo Volcanic Zone arc system, New Zealand. New Zealand Journal of Geology and Geophysics. 36:417-435.

Hayward BW. 2017. Out of the ocean, into the fire: history in the rocks, fossils and landforms of Auckland, Northland and Coromandel. Lower Hutt: Geoscience Society of New Zealand. Geoscience Society of New Zealand Miscellaneous Publication 146.

Herzer RH, Davy BW, Mortimer N, Quilty PG, Chaproniere GCH, Jones CM, Crawford AJ, Hollis CJ. 2009. Seismic stratigraphy and structure of the Northland Plateau and the development of the Vening Meinesz transform margin, SW Pacific Ocean. Marine Geophysical Researches. 30:21-60. 
Ireland TR. 1992. Crustal evolution of New Zealand: evidence from age distributions of detrital zircons in Western Province paragneisses and Torlesse greywacke. Geochimica et Cosmochimica Acta. 56:911-920.

Isaac MJ, Herzer RH, Brook FJ, Hayward BW. 1994. Cretaceous and Cenozoic sedimentary basins of Northland, New Zealand. Institute of Geological and Nuclear Sciences Monograph 8.

Jackson SE, Pearson NJ, Griffin WL, Belousava EA. 2004. The application of laser abalationinductively coupled plasma-mass spectrometry (LA-ICP-MS) to in situ U-Pb zircon geochronology. Chemical Geology. 211:47-69.

Leonard GS, Begg JG, Wilson CJN. 2010. Geology of the Rotorua area. Institute of Geological \& Nuclear Sciences 1:250,000 Geological Map 5. Lower Hutt, Institute of Geological \& Nuclear Sciences.

Ludwig KR 2003. Users' manual for Isoplot/Ex version 3.0. A geochronological toolkit for Microsoft Excel. Berkely Geochronological Center Special Publication 3.

Mortimer N. 1994. Origin of the Torlesse Terrane and coeval rocks, North Island, New Zealand. International Geology Review. 36:891-910.

Mortimer N. 2008. Zealandia. In: Spencer JE, Titley SR, editors. Ores and orogenesis: circum-Pacific tectonics, geologic evolution and ore deposits. Tucson, Arizona, USA: Arizona Geological Society Digest. 22:227-233.

Parson LM, Wright IC. 1996. The Lau-Havre-Taupo back-arc basin: a southwardpropagating, multi stage evolution from rifting to spreading. Tectonophysics. 263:1-22.

Price RC, Mortimer N, Smith IEM, Maas R. 2015. Whole-rock geochemical reference data for Torlesse and Waipapa terranes, North Island, New Zealand, New Zealand Journal of Geology and Geophysics. 58:213-228.

Raine JI, Beu AG, Boyes AF, Campbell HJ, Cooper RA, Crampton JS, Crundwell MP, Hollis CJ, Morgans HEG, Mortimer N. 2015. New Zealand Geological Timescale NZGT 2015/1. New Zealand Journal of Geology and Geophysics. 58:398-403.

Ryan WBF, Carbotte SM, Coplan JO, O'Hara S, Melkonian A, Arko R, Weissel RA, Ferrini V, Goodwillie A, Nitsche F, Bonczkowski J, Zemsky R. 2009. Global multi-resolution topography synthesis. Geochemistry, Geophysics, Geosystems. 10:Q03014, doi10.1029/2008GC002332. 
Spörli KB. 1978. Mesozoic tectonics, North Island, New Zealand. Geological Society of America Bulletin. 89:415-25.

Strong DT, Turnbull RE, Haubrock SN, Mortimer N. 2016. Petlab: New Zealand's national rock catalogue and geoanalytical database. New Zealand Journal of Geology and Geophysics. 59:475-481.

Sutherland R. 1999. Basement geology and tectonic development of the greater New Zealand region: an interpretation from regional magnetic data. Tectonophysics. 308:341-362.

Wright, IC 1997. Morphology and evolution of the remnant Colville and active Kermadec arc ridges south of 3330'S. Marine Geophysical Researches. 19:177-193.

Wright IC, Parson LM, Gamble JA. 1996. Evolution and interaction of migrating cross-arc volcanism and backarc rifting: an example from the southern Havre Trough $\left(35^{\circ} 20^{\prime}-\right.$ $37^{\circ}$ S). Journal of Geophysical Research. 101:22071-22086.

Wysoczanski RJ, Todd E, Wright IC, Leybourne MI, Hergt JM, Adam C, Mackay K. 2010. Backarc rifting, constructional volcanism and nascent disorganised spreading in the southern Havre Trough backarc rifts (SW Pacific). Journal of Volcanology and Geothermal Research. 190:39-57.

Wysoczanski RJ, Leonard G, Gill J, Wright IC Calver A, McIntosh W, Jicha B, Gamble JA, Timm C, Handler M, Drewes E, Zohrab A. 2019. Ar-Ar age constraints on the timing of Havre Trough opening and magmatism. New Zealand Journal of Geology and Geophysics, doi.org/10.1080/00288306.2019.1602059. 


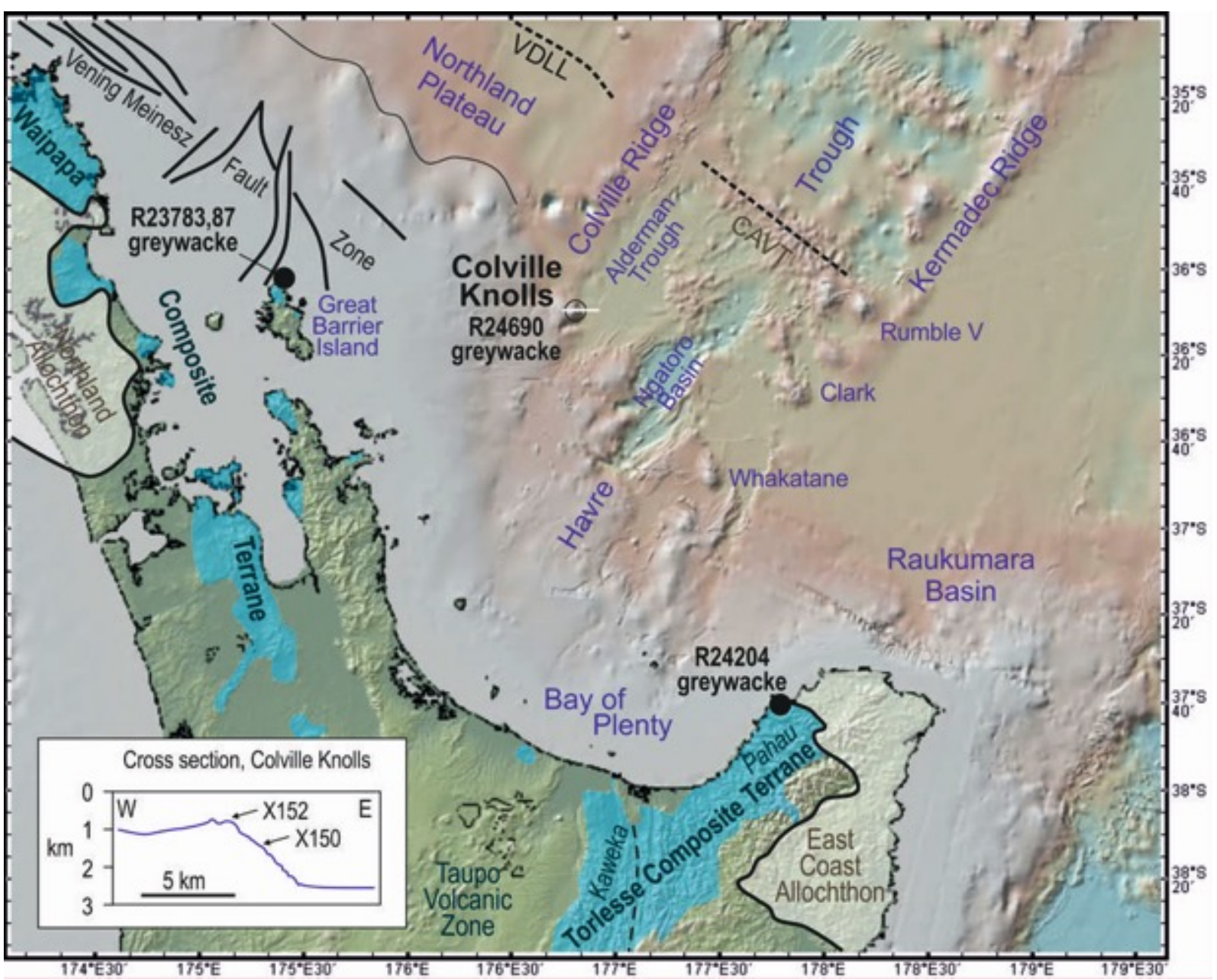

Figure 1. Location of Colville Knolls and other selected bathymetric and geological features of the region. Background image is global multi-resolution topography (http://www.geomapapp.org; Ryan et al. 2009). Cross section of dredge sites based on multibeam data from Nathaniel B Palmer 9504 cruise. Geological features based on Isaac et al. (1994) and Leonard et al. (2010). Sample sites from Adams et al. (2012, 2013). VDLL $=$ van der Linden Lineament of Sutherland (1999). CAVT=one of the cross-arc volcanic trails of Wright et al. (1996). 


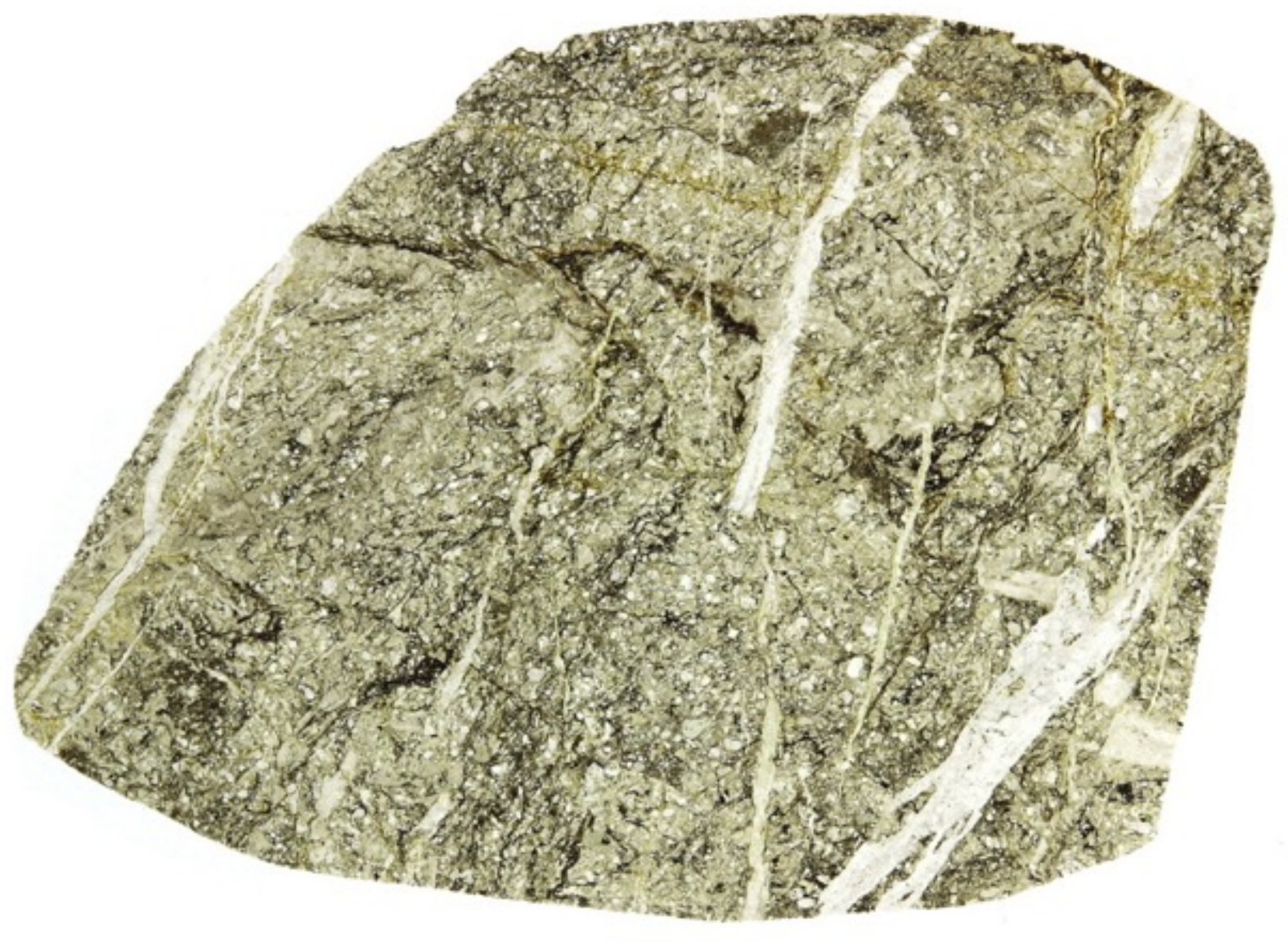

Figure 2. Plane-polarised light image of thin section of dated sample R24690 (P78547). Image height c. $20 \mathrm{~mm}$. 

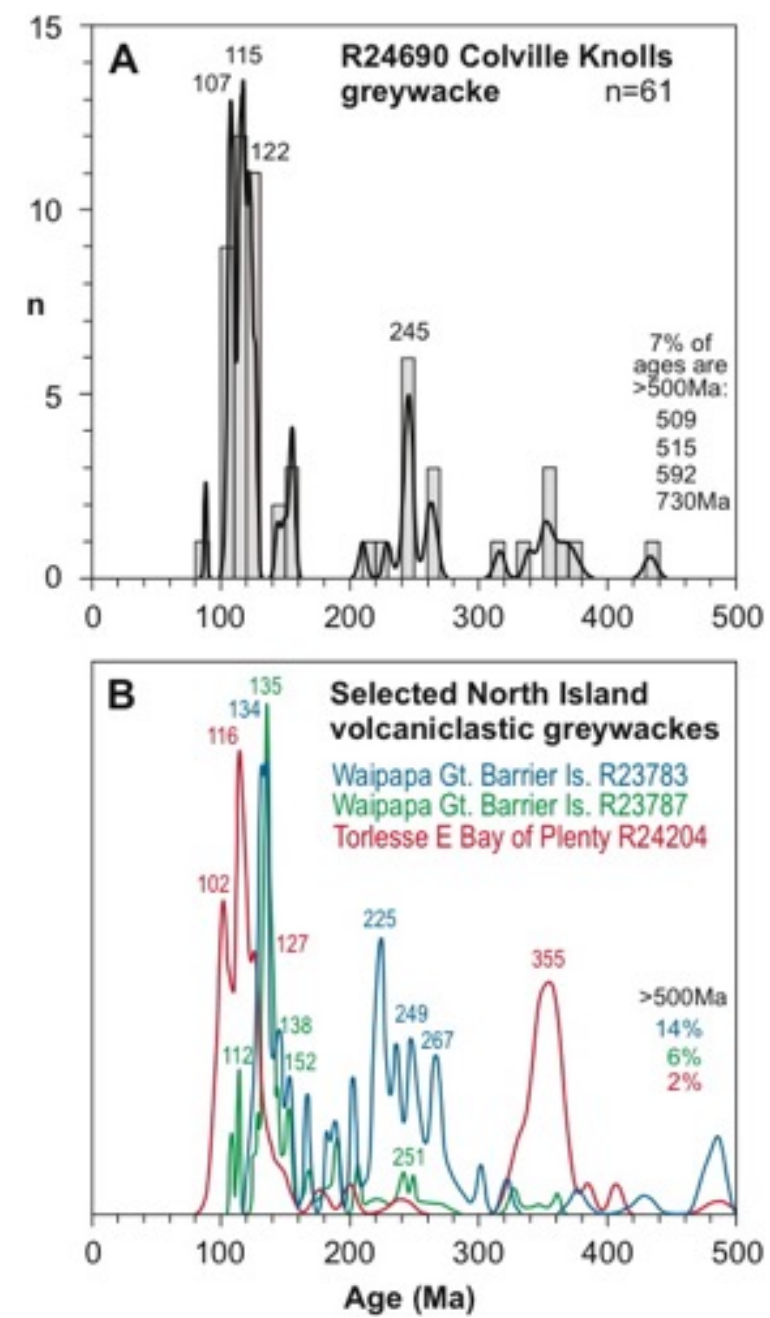

Figure 3. Detrital zircon age spectra. A, histogram, probability density function and significant component ages of Colville Knolls greywacke sample R24690. B, probability density function references of three North Island Cretaceous volcaniclastic greywacke sandstones R23783 and 23787 from Great Barrier Island (Adams et al. 2013) and R24204 from Whanarua Bay (Adams et al. 2012). 